Article

\title{
Between the Center and the Margins: Young Catholics, "Sorta-Catholics," and Baptismal Identity
}

\section{Rhodora Beaton}

Department of Liturgical and Sacramental Theology, Aquinas Institute of Theology, Saint Louis, MO 63108, USA; beaton@ai.edu

Received: 1 August 2019; Accepted: 30 August 2019; Published: 3 September 2019

\begin{abstract}
Increased pastoral and theological attention to the vocational implications of baptism is sorely needed. As a small contribution to this conversation, this article will examine the insights of young Catholics and their self-described "former Catholic" peers (ages 15-29) regarding key aspects of the Christian life. These insights offer a foundation for evolving understandings of baptismal identity at both the center and the margins of the church. Two recent efforts to formally solicit the opinions of young people will be examined. They are the Pre-Synodal preparations for the 2018 Synod on Young People and the recent study, published by Saint Mary's Press in collaboration with the Center for Applied Research in the Apostolate (CARA) under the title Going, Going Gone: The Dynamics of Disaffiliation in Young Catholics. The responses from these young people, placed in conversation with recent theological work on baptism and the lay vocation, offer possibilities for consideration as Catholics ponder the changing demographics of the Church. The conclusion will argue for the urgent necessity of listening to these voices and will suggest that a mystagogical approach offers one helpful path towards a deeper understanding and practice of the baptismal vocation.
\end{abstract}

Keywords: baptism; vocation; Synod on the Youth; laity; mystagogy; disaffiliation; Second Vatican Council

\section{Introduction}

In the first decades of the twenty-first century, the number of lay Catholics celebrating the sacraments of initiation and matrimony has declined precipitously in the US. According to recent Center for Applied Research in the Apostolate (CARA) data, the number of Catholic marriages decreased from 261,626 in the year 2000 to 143,082 in 2017. Perhaps even more striking, 335,832 fewer infants were baptized in 2017 than in 2000. The number of adult baptisms also dropped by approximately $50 \%$. By contrast, ordinations to the priesthood and diaconate have steadily increased, alongside a respectable increase in the number of lay ecclesial ministers, including vowed religious, in parish ministry ${ }^{1}$ (CARA 2019). While the reasons for these shifts are both varied and beyond the scope of this paper, the patterns point to theological as well as pastoral challenges.

One of the challenges that has accompanied these shifts is the need for a more adequate understanding of the Christian vocation of the laity that has traditionally been rooted in baptism. While the lay vocation is commonly associated with baptism, the baptismal rites say nothing about "the laity," although they speak both literally and symbolically about the theological realities of Christian life. This focus is especially clear in the Rite of Christian Initiation of Adults in which pre- and post-baptismal formation are framed by liturgical reflection on the experience of the Christian "mysteries" of Scripture

1 Presbyteral ordinations, which hit a low point of 442 in 2000, have risen to 504 in 2017. The number of permanent deacons has also continued its steady increase from 12,378 in 2000 to 18,287 in 2017 CARA indicates that there were 29,146 lay ecclesial ministers in parish settings in 1995 and 39,651 in 2014. Data not available for 2000 or 2018 (CARA 2019). 
and the sacraments, as well as by works of charity (International Commission on English in the Liturgy [1988] 1990, nos. 75, 244). Magisterial texts that take an ecclesiological rather than liturgical focus, often reference baptism, but do not engage the ritual texts directly. Vatican II's Decree on the Laity, for example, mentions baptism only once, stating that "The laity derive the right and duty to the apostolate from their union with Christ the head; incorporated into Christ's Mystical Body through Baptism and strengthened by the power of the Holy Spirit through Confirmation, they are assigned to the apostolate by the Lord Himself" (Apostolicam actuositatem [1965] 1996, no. 3). Lumen gentium devotes nine paragraphs to the laity, although it does so most frequently in terms of the laity's relationship to the bishops. The text defines "laity" as "all the faithful except those in holy Orders and those who belong to a religious state approved by the church: all the faithful, that is, who by Baptism are incorporated into Christ, are constituted the people of God, who have been made sharers in their own way in the priestly, prophetic and kingly office of Christ and play their part in carrying out the mission of the whole Christian people in the church and in the world. To be secular is the special characteristic of the laity" (Lumen gentium [1964] 1996, no. 31.) It is this secular characteristic which will be emphasized both in the subsequent paragraphs of Lumen gentium and later in Pope John Paul II's Post-Synodal Apostolic Exhortation Christifideles laici (John Paul II 1988, nos. 15, 17, 22-23).

In the twenty-first century, an age in which both marriages and baptisms have declined, even as the number of disaffiliated Catholics has increased, the question of the Christian vocation rooted in baptism takes on greater urgency. Despite the post-Vatican II efforts of theologians, pastors, and campus ministers, the young people who contributed to the Final Document of the 2018 Pre-Synodal Meeting of Young People held at the Vatican, maintain that "the term 'vocation' has become synonymous with the priesthood and religious life in the culture of the Church" (Pre-Synodal Meeting of Young People 2018, no. 8). Exclusive even of marriage or consecrated life, such a viewpoint can seem to leave little theological guidance for the increasing number of young, and not-so-young, lay people who do not experience a call to any of these states of life. Pope Francis addresses this issue very briefly in his Post-Synodal Apostolic Exhortation Christus vivit, writing "For those who are not called to married or the consecrated life, it must always be remembered that the first and most important vocation is the vocation we have received in baptism. Those who are single, even if not by their own choice, can offer a particular witness to that vocation through their own path of personal growth" (Francis 2019, no. 267). The fact that even the pope directs his observation specifically towards those who are not called to marriage or consecrated life seems to undermine his point that "the most important vocation is the [one] that we receive in baptism." Do those who are called to marriage or the consecrated life not also need to remember this "most important vocation"? More than a sacrament that grounds the Christian vocation as a whole, in practice baptism is often treated like a pre-vocational sacrament that lays the groundwork for marriage, religious life or holy orders. Despite efforts to the contrary, this ingrained approach diminishes the significance of both the rites of baptism and the Christian vocation in the world.

Increased pastoral and theological attention to the vocational implications of baptism is sorely needed. As a small contribution to this conversation, this article will examine the insights of young Catholics and their self-described "former Catholic" peers (ages 15-29) regarding key aspects of the Christian life. These insights can offer a foundation for evolving understandings of baptismal identity at both the center and the margins of the church. We will first examine two recent efforts to formally solicit the opinions of young people. These venues are the Pre-Synodal preparations for 2018 Synod on Young People, the Faith, and Vocational Discernment and the recent study, published by Saint Mary's Press in collaboration with the Center for Applied Research in the Apostolate in September 2017 under the title Going, Going Gone: The Dynamics of Disaffiliation in Young Catholics. The responses from these young people, placed in conversation with recent theological work on baptism and the lay 
vocation, offer several avenues for consideration as Catholics ${ }^{2}$ ponder the changing demographics of the Church and the changing needs of those among the baptized who, as the young people at the Pre-Synodal meeting put it, "see vocation as inclusive of life, love, aspiration, place in and contribution to the world, and way to make an impact" (Pre-Synodal Meeting of Young People 2018, no. 8). This paper will argue for the urgent necessity of listening to these voices. As a partial response, it will also suggest that a mystagogical approach, grounded in the liturgical experience of the rites can offer one path towards a deeper understanding and practice of the baptismal vocation. It is out of this liturgical experience that, as the Rite of Christian Initiation of Adults puts it, "belongs to Christians and increases as it is lived, ... new perceptions of the faith, of the Church, and of the world" might be derived (International Commission on English in the Liturgy [1988] 1990, no. 245), and a path towards a deeper understanding of the baptismal vocation might be found in community.

\section{A Word about the Sources}

The experiences and opinions of lay Roman Catholics are rarely formally solicited by national or international ecclesiastical structures. In the past decade however, due perhaps to the alarmingly declining number of lay people at liturgies, both the Vatican and a small Catholic publisher in the state of Minnesota sought to ask young Catholics directly about their experiences. While these approaches differed, in both cases, substantial feedback was forthcoming.

The Saint Mary's Press/CARA study focused specifically on "surveying and interviewing youth and young adults (ages 15-25) who once self-identified as Catholic, but no longer do so" (Saint Mary's Press of Minnesota and CARA 2017, p. 5). The study, which relied on both qualitative and quantitative data, isolated three distinct categories of the disaffiliated: the Injured, the Drifter, and the Dissenter. It was also clear that "often departure from the Catholic faith is rooted primarily in one of the three main categories, but rarely can disaffiliation be assigned to just one category or cause-and even all three may be involved" (Saint Mary's Press of Minnesota and CARA 2017, p. 13). The authors emphasize the importance of the qualitive data "to illuminate ... the reality that behind every life story is a 'name.'" These are names that, most likely, were given in baptism and recorded in parish record books. The authors of the study remind the reader that "each person who disaffiliates has a name, a story, and longings of the heart and mind" (Saint Mary's Press of Minnesota and CARA 2017, p. 7). As indicated in their responses, these baptized individuals continue to seek the good as they understand it but have chosen to do so outside of the Catholic community. They challenge the Church, the authors of the study indicate, to ask: "Can we prioritize families on the margins?...Can we provide religious formation that address the important issues and questions that young Catholics are thinking about at earlier and earlier ages?...How do we define what it means to 'be Catholic'?.... How aware are we of the rise of the 'sorta-Catholic' or 'Catholic-ish' young people (and adults) — those with a tenuous relationship or connection to the Church? Do we fully embrace these young people as 'valid' Catholics, knowing they don't fully accept and embrace the fullness of the Church's teachings and practices?" (Saint Mary's Press of Minnesota and CARA 2017, p. 35). These Catholics "on the margins" may also have existed in the past, but their more visible absence today raises important questions about what the baptized but not practicing experience is like, as well as what can or should be expected from baptism and/or the baptized.

One might ask "why the margins?" Why not simply focus on the young people who have remained Catholic, some of whom offered their insights to the bishops of the synod, and hear from them about what has "worked"? Aside from an obvious concern for evangelization, or in some cases re-evangelization, the methodological emphasis on the "margins" has become important both

2 Although the challenges of baptismal identify affect and are being addressed by many Christian denominations, this article will focus primarily on the Roman Catholic context. Given the limits of the Saint Mary's Press/CARA study, the focus is also necessarily reflective of the United States Catholic experience. 
theologically and pastorally, particularly in the pontificate of Pope Francis. Richard Gaillardetz suggests that this emphasis has its foundations in the conciliar theology of Yves Congar (Gaillardetz 2014, p. 70), who points out that "most of the time, initiatives do not come from the center but from the periphery" (Congar [1967] 2011, p. 239). Congar observes that "the margin is closer to the periphery than to the center .... the center, with its vocation to oversee structure, prefers something defined to something that is searching and striving for expression. Yet a spiritual organism is more likely to grow out of the elements searching and striving for expression" (Congar [1967] 2011, p. 240). The young people who were interviewed for the qualitative element of the Saint Mary's Press/CARA study were striving for expression. Some had wanted to tell their story but had not yet had the opportunity to do so (Saint Mary's Press of Minnesota and CARA 2017, p. 7). As Gaillardetz, Congar, and Pope Francis point out, the Church needs both the center and the margins. If the center maintains the structure, the margins offer a place for growth, even if that place becomes somewhat frayed or unruly.

The Synod on Young People, the Faith, and Vocational Discernment was held in Rome in October of 2018. In addition to the bishops with voting rights, ecumenical observers and young auditors also attended. The preparation for this meeting included the input of many young lay people. As the synod website puts it quite bluntly, "the will to speak to youths directly was something specifically new" (General Secretariat of the Synod of Bishops 2018b). The initiative to speak directly took several manifestations. The first of these took the form of an online questionnaire, accessible in a variety of languages and available from June-December 2017. The Vatican reports that "more than 200,000 made contact (with more than half who filled it out completely)" (General Secretariat of the Synod of Bishops 2018b). While participation in the questionnaire was both open and voluntary and much about the participants remains unverified, it was directed to people 16-29 years of age. ${ }^{3}$ In addition to the survey, three hundred young people, including representatives from other religions, gathered in Rome for a pre-synodal meeting in March 2018. They were accompanied by an additional fifteen thousand virtual participants through social media. According to the synod website, "for one week, these participants exchanged views by elaborating their reflections which were merged into a document that expresses (with doubts, uncertainties, desires and hopes) the thoughts and experiences of young people in the 21st century" (General Secretariat of the Synod of Bishops 2018b). Among the delegates sent from the United States were a religious brother who teaches high school, a single man who serves as director of campus ministry at a Catholic university, and a married woman who is a mother and a youth minister (United States Conference of Catholic Bishops 2019). ${ }^{4}$ As part of their work together, this group produced a document titled "Young People, The Faith and Vocational Discernment: Pre-Synodal Meeting Final Document," as a guide for the synod itself (Pre-Synodal Meeting of Young People 2018).

While the young and disaffiliated of the Saint Mary's Press/CARA study and the young people chosen by their bishops to represent their countries may seem entirely different from one another, their responses indicate that the connections between them remain relatively intact. For example, one subject of the Saint Mary's Press/CARA study observes that "most of my friends are still Catholic and maybe, like if I have somebody [in my life], I could return to the Catholic Church" (Saint Mary's Press

3 The full results of this study are available on the synod website. The English translation, entitled, "The World of New Generations According to the Online Questionnaire" begins on page 81 (General Secretariat of the Synod of Bishops 2018a).

4 The USCCB website describes the delegates chosen by the USCCB as follows: “Br. Javier Hansen, FSC, originally from northern California, is a Brother of the Christian Schools in the Lasallian District of San Francisco-New Orleans, currently serving as a religion teacher at Cathedral High School-El Paso, Texas; Nick López, originally from San Antonio, currently serves as the director of campus ministry for the University of Dallas. He is also a guest columnist for the Catholic News Service column, In Light of Faith, focused on millennials; [and] Katie Prejean McGrady, of the Diocese of Lake Charles in Louisiana, is a wife, new mother, youth minister, and a popular speaker who has been working with many youth and young adult communities across the country." It is also noted that "there will be other delegates at the Pre-Synod representing other groups (i.e., Eastern Rite Catholic Churches, various apostolates and movements) who live in the U.S." (United States Conference of Catholic Bishops 2019). Katie Prejean McGrady, who wrote about her experience in America Magazine, described the process as "an effort to help the bishops understand precisely what is going on with people of a certain age so that they can then better understand how to preach to, teach thoroughly and accompany youth and young adults" (McGrady 2018). 
of Minnesota and CARA 2017, p. 24). The researchers themselves observe that many of the disaffiliated young people are not "closed to belief (or fuller belief)" (Saint Mary's Press of Minnesota and CARA 2017, p. 30). Similarly, the young people participating in the Pre-Synodal Meeting of Young People, including those of other religions, indicate that they are likewise in relationship with disaffiliated peers. They sought to represent not only themselves or other practicing Catholics, but also "lots of young people [who have] lost trust in institutions, have become disaffiliated with organized religion and would not see themselves as 'religious'"' (Pre-Synodal Meeting of Young People 2018, no. 5). These groups are clearly distinct, yet it is also clear that they do not exist in isolation from one another; the "center" and the "margins" are not as distant as one might expect. As Paul Crowley has observed "contemporary Christians in the Western world inhabit the very same world as their atheist or agnostic friends and make many of the same basic assumptions about how reality is structured and functions ... Some have lost the ability to believe, not because they do not know what the church has proposed for belief, but because the doctrinal 'content' of faith has become intellectually incredible, as belonging to another world of meaning and reference and certainly not to the world of empirical demonstration" (Crowley 2015, p. 8). This world that contemporary Christians share with their atheist and agnostic friends is the context in which contemporary baptismal identity is lived out, strengthened, or rejected. The themes and struggles that emerge from the insights of these young baptized Christians therefore have much to say about the future of the Church in the contemporary world.

\section{Baptism and the Christian Life: Implicit Expectations}

The second half of the twentieth century witnessed the emergence of the sacrament of baptism from shadowy sacristies into the brightness of Sunday morning liturgies. New baptistries with fonts suitable for full-immersion were constructed and have become striking focal points for parish liturgy. With the revision of the Easter Triduum in the late 1950s and the increasingly normative theology of the Rite of Christian Initiation of Adults, this once private, family-oriented sacrament has reclaimed its public space in the Church and world. As a result, Catholics witness baptisms more frequently and at least some, quite reasonably, seem to expect that the sacrament ought to have a noticeable effect. Concerns about this effect are at the root of both challenges and possible developments in the search for a theology of the baptismal vocation to the Christian life. As might be expected, the document produced by the Pre-Synodal Meeting of Young People articulates the concerns of this generation in greater theological nuance than the individual survey responses and interviews of the Saint Mary's Press/CARA study. In both cases, despite the different outcomes in terms of relationship to the institutional church, it is clear that some of the key teachings of the Second Vatican Council, particularly those associated with baptism and the lay vocation have taken root. Among these are a deep concern and expectation for holiness as a mark of Christian life; a desire to read the signs of the times and address social issues with an appreciation for the human dignity of all people, particularly those on the margins; and finally, a desire for more substantial theological education. We will consider each of these issues raised in the responses of the young people in light of the documents of the Second Vatican Council and related scholarship in the contemporary Roman Catholic theological context.

In the minds of young Catholics at both the center and the margins, a concern with holiness, or in some cases, a deep concern with a perceived lack of holiness, takes center stage. In the category of "The Injured," the Saint Mary's Press/CARA study considered the role of the Church community in the experience of young Catholics who left the Church due to a negative experience. Although the word "holiness" did not necessarily come up directly, some former Catholics root their decision to disaffiliate in a perception of "the Church as inauthentic or hypocritical ... This was especially true if a young person perceived a family member's everyday attitudes or behaviors as unethical or immoral, yet that same family member attended church on Sunday and otherwise professed belief in the Catholic faith" (Saint Mary's Press of Minnesota and CARA 2017, p. 15). As one individual put it, "it was just like the feeling of not feeling like you are part of something because sometimes you have these people that are extremely religious and then they become extremely hypocritical and they think they are better 
than everybody else. But they do these bad things and it's like, how could you be part of that?" (Saint Mary's Press of Minnesota and CARA 2017, p. 16). In these cases, it was the witness (or lack thereof) of other lay Catholics that disrupted the faith journey of a young and perhaps already marginal Catholic. The young people might have had high expectations of other Catholics in part because of the influence of Lumen gentium's teaching that the universal call to holiness is rooted in the sacrament of baptism. In light of the possible consequences of disaffiliation, the Council's exhortation that all the baptized "must therefore hold on to and perfect in their lives that holiness which they have received from God" takes on a sharper meaning: "All Christians ... are called ... to the perfection of charity and this holiness is conducive to a more human way of living even in society here on earth" (Lumen gentium [1964] 1996, no 40). When this vocational call to charity and holiness remains unanswered, or fails to be evident in Christian life, harm is done to the most vulnerable members of the community; they are pushed even farther to the margins.

The young people represented at the Pre-synodal Meeting express a similar sentiment. These generational peers of the disaffiliated observe that "young people are attracted to the joy which should be a hallmark of our faith. Young people express a desire to see a Church that is a living testimony to what it teaches and witnesses to authenticity on the path to holiness, which includes acknowledging mistakes and asking for forgiveness" (Pre-Synodal Meeting of Young People 2018, no. 9). In this case, the concern seems not to be so much with family members or classmates, but with "leaders of the Church-ordained, religious and lay." This authenticity becomes a form of inspiration on the path to holiness. The young people at the Pre-Synodal Meeting do not necessarily require the "perfection" that Lumen gentium exhorts, but they clearly call for a witness that is joyful, authentic, and willing to acknowledge failure in order to seek forgiveness.

In the contemporary context, similar issues regarding the relationship between baptism and the Christian life have been raised in the field of moral theology. Christian ethicist Katie Grimes, for example, has recently argued that "the vice of white supremacy pervades the church's corporate body and thereby permeates all of its practices, including those of baptism and Eucharist" (Grimes 2017a, p. 22). Due to practices such as forced baptisms, and the radical social inequality between enslaved peoples and white, Christian, masters, Grimes argues that the ritual symbols of baptism have been hopelessly corrupted and will not be efficacious again until the Church has worked to dismantle white supremacy in the world. ${ }^{5}$ She writes: "Performed under conditions of antiblackness supremacy, baptism became perverse: it ushered slaves not out of bondage and into freedom, but from freedom and into bondage. It brought slaves not out of death and into life, but from life and into death, both social and physical" (Grimes 2017b, p. 195). Rejecting the work of previous scholars who have viewed baptism as a potential source of healing for the injustices of the world, Grimes regards it as something that should be holy, but is currently perverse in its corruption.

Young Catholics associate holiness and authenticity. If someone or something is expected to be holy, then it ought to be holy. As the Pre-synodal group recognizes, failure, repentance, and forgiveness can be experienced along "the path to holiness" as a model of authenticity and Christian vulnerability. As the disaffiliated youth and Grimes point out, it is too often the case that baptized Christians fail (or refuse) to recognize the harm that they have done and therefore do not progress along the path to repentance and forgiveness. Individually or collectively, they may veer from the path of holiness, leaving scandal rather than sanctification in their wake. When baptism is celebrated as an isolated ritual, public as it may be, the disconnect between liturgical celebration and Christian life can become a source of harm rather than a sacramental sign of the presence of Christ in the liturgy and in the world.

If Vatican II's emphasis on holiness, especially to be found in Lumen gentium, has helped to shape the thinking of a generation, it is also the case that Gaudium et spes's emphases on the importance

5 See also (Grimes 2017b, pp. 189-204). See also, for example Christiana Zenner's Just Water: Theology Ethics and Fresh Water Crises in which she asks, "if the water of the Jordan River is polluted, pea-green, and degraded, is it really so holy?" (Zenner 2018, p. 188). 
of engagement in the modern world and the dignity of the human person has struck an important chord. Massimo Faggioli has suggested that "Gaudium et spes is the real test for the council's impact on the church's theological tradition ... . The church's historicity is not about looking back but about moving forward ad extra" (Faggioli 2012, p. 813). In both the disaffiliated group and in the group of young people at the Pre-Synodal Meeting, we see a resonance with and reception of the message of the preface to Gaudium et spes. It is clear that "the joys and hopes, the grief and anguish of the people of our time, especially of those who are poor or afflicted, are the joys and hopes, the grief and anguish of" many of the young people involved. They seem to believe that the Church does indeed carry "the responsibility of reading the signs of the times and of interpreting them in the light of the Gospel" (Gaudium et spes [1965] 1996, no. 4) even though they admit to disagreement regarding the proper tack to take moving forward. The young people involved in the Saint Mary's Press and CARA study express concerns about "LGBT people being stigmatized," about healing for the sick and the elderly, and about a lack of solidarity with or even tolerance for those whom they perceived to be suffering or excluded due to the actions of local Catholic communities (Saint Mary's Press of Minnesota and CARA 2017, pp. 15, 17, 57). Mostly in the study's category of "the Injured," these young people seem to be less concerned with doctrinal issues and more concerned with the outward practices of Christian living in their communities. The anguish of those who are suffering has become their anguish (or anger) as baptized members of the Church, and yet they do not see that the same anguish is shared by those who are in authority.

The Pre-Synodal text also takes up issues of the Church ad extra. "The young Church also looks outward; young people have a passion for political, civil and humanitarian activities. They want to act as Catholics in the public sphere for the betterment of society as a whole. In all aspects of Church life, young people wish to be accompanied and to be taken seriously as fully responsible members of the Church" (Pre-Synodal Meeting of Young People 2018, no. 12). These young people have embraced the message of Gaudium et spes, and, perhaps in light of the teachings of Lumen gentium, also understand themselves as "fully responsible members of the Church" who share in the experiences of "the people of our time." More specifically, they are "concerned about topics such as sexuality, addiction, failed marriages, broken families, as well as larger-scale social issues such as organized crime, human trafficking, violence, corruption, exploitation, femicide, all forms of persecution and the degradation of our natural environment. [They note that] these are of grave concern in vulnerable communities around the world" (Pre-Synodal Meeting of Young People 2018, no. 1). While some of these issues have also been taken up by the magisterium, it is clear that these young people wish to work personally and as a community to "address the social justice issues of our time" (Pre-Synodal Meeting of Young People 2018, no. 3). Although they do not necessarily agree with each other or with the magisterium on the best approach to these topics, ${ }^{6}$ young people are aware of and engaged with the struggles of the modern world. They expect that the Church will play a productive role in addressing these challenges and they expect that their participation as "fully responsible members" will be welcomed. Some of them wish to be included in this effort as Catholics, while others no longer wish to be Catholic because they see Catholic identity as an impediment to the contribution that they wish to make.

6 The Pre-Synodal document observes that "there is often great disagreement among young people, both within the Church and in the wider world, about some of her teachings which are especially controversial today .... What is important to note is that irrespective of their level of understanding of Church teaching, there is still disagreement and ongoing discussion among young people on ... polemical issues [including] contraception, abortion, homosexuality, cohabitation, marriage, and how the priesthood is perceived in different realities of the Church" (Pre-Synodal Meeting of Young People 2018, no. 5). Similarly, the Saint Mary's Press/CARA study notes that "Dissenting young people who actively leave the Church express disagreement with Church teachings on many social issues, particularly same-sex marriage, abortion, and birth control, though the abortion issue seems nuanced in that there is often opposition to abortion, but support for an individual's right to choose that option" (Saint Mary's Press of Minnesota and CARA 2017, p. 21). 
In a related way, we also see in both groups a concern for human dignity, the topic of the first chapter of Gaudium et spes and an overarching theme throughout the document. The Pre-synodal document takes up this topic in light of contemporary issues such as racism and the role of women in society observing that "racism at different levels affects young people in different parts of the world" (Pre-Synodal Meeting of Young People 2018, no. 2). In a related point, these young people lament that "there is still no binding consensus on the question of welcoming migrants and refugees, or on the issues which cause the phenomenon in the first place. This is despite the acknowledgment of the universal call to care for the dignity of every human person" (Pre-Synodal Meeting of Young People 2018, no. 2). Later in the document, they express a concern for the promotion of "the dignity of women, both in the Church and in wider society [noting that] today, there is a general problem in society that women are still not given an equal place. This is also true in the Church" (Pre-Synodal Meeting of Young People 2018, no. 5). Although there are no footnotes here, the echo of Gaudium et spes's endorsement of the "equal dignity as persons" that is due to everyone regardless of "sex, race, color, social conditions, language, or religion" (Gaudium et spes [1965] 1996, no. 29) seems evident.

The Saint Mary's Press/CARA study of disaffiliated young people echoes some of these concerns and also considers the dignity that Gaudium et spes associates with religious freedom. According to the authors of the study one of the most common reasons for disaffiliation is the belief "that religion was forced on [an individual] and they are determined to not force religion/religious practice or a particular faith on their own children. Religion and religious practice ought to be a free choice, they argue" (Saint Mary's Press of Minnesota and CARA 2017, p. 27). A related, if significantly more mildly stated, sentiment can be found in the Pre-synodal text's description of the ideal mentor: "They should respect the freedom that comes with a young person's process of discernment and equip them with tools to do so well .... A mentor should nurture the seeds of faith in young people, without expecting to immediately see the fruits of the work of the Holy Spirit" (Pre-Synodal Meeting of Young People 2018, no. 10). While this interpretation is perhaps not what the authors of Gaudium et spes had in mind, one can find here an echo of the Council's conviction that the dignity of human beings "requires them to act out of conscious and free choice as moved and drawn in a personal way from within, and not by their own blind impulses or by external constraint" (Gaudium et spes [1965] 1996, no. 17). One could certainly argue about the adequacy of conscience formation, ${ }^{7}$ as well as about theological understandings of human freedom and parental obligations; however, these young people express a particular and emphatic respect for the dignity of their own children to act without external constraint especially in the realm of religious practice. Although some intend to teach their children about the existence of God, this subgroup is particularly adamant that it is both inappropriate and ineffective to force a child to participate in religious practices. As one young person put it, "I want her to have freedom of what she wants to do rather than it being forced upon her." Another observes "I do know that the more a person forced me back then and the harder, the more pushback I gave them. I think that would be the best advice I could give is just be open and don't be forceful and that will likely keep somebody in the same direction that they are going" (Saint Mary's Press of Minnesota and CARA 2017, pp. 27-29). These disaffiliated young people regard forced religious formation as both counter-productive and contrary to a child's dignity as a human person.

Finally, both groups articulate the need for more substantial theological formation. In some cases, this formation pertains to theological approaches to controversial social issues. In other cases, it has to do with as diverse topics as the perceived disconnect between science and religion, misunderstandings of the Catholic faith, and inadequate sacramental preparation. As the Pre-Synodal document puts it, young people "long for experiences that can deepen our relationship with Jesus in the real world" (Pre-Synodal Meeting of Young People 2018, no. 14). There is a sense here that both experiential and intellectual approaches are needed. In terms of their desire for experiential formation, the Pre-Synodal

7 For one analysis of these contemporary complications, see (Cox 2015, pp. 82-100). 
group describe themselves as "more receptive to a 'literature of life' than an abstract theological discourse" (Pre-Synodal Meeting of Young People 2018, no. 5). The authors of the Saint Mary's Press/CARA study echo this self-reflection in their analysis, observing that "personal experience is the default mediator of meaning and truth for these young people" (Saint Mary's Press of Minnesota and CARA 2017, p. 24). As their approach to holiness indicates, the reality must reflect the description.

Despite, or perhaps because of, this emphasis on personal experience, young people "ask that our leaders speak in practical terms about controversial subjects such as homosexuality and gender issues, about which young people are already freely discussing without taboo" (Pre-Synodal Meeting of Young People 2018, no. 11). In these topics, the connection between experience and intellectual understanding becomes especially clear. We see a strong desire to engage the theological and ethical issues of the contemporary world in ways that are authentic and particular. "The young have many questions about the faith, but desire answers which are not watered-down, or which utilize pre-fabricated formulations" (Pre-Synodal Meeting of Young People 2018, no. 11). As one of the subjects of the Saint Mary's Press/CARA study put it more bluntly: "it didn't quite make much sense to me and I never felt like I was receiving satisfactory answers from my CCD teachers" (Saint Mary's Press of Minnesota and CARA 2017, p. 23). Some of these questions have to do with ethics, while others seem to span the theological disciplines regarding "fundamental questions about the beliefs of the catholic church and faith" (Saint Mary's Press of Minnesota and CARA 2017, p. 62). Another respondent said: "when I was 15 I read the bible, cover to cover ... . The actual bible was wildly different and even more strict than what I knew to be true in my heart. After my reading I went to a priest at my church. His answers were extremely noncommittal and dismissive, maybe because I was young, but it was an extremely frustrating experience for me" (Saint Mary's Press of Minnesota and CARA 2017, 64). There is a frustration here both with the inadequacy of "pre-fabricated" answers and with a sense that serious theological questions are not being taken seriously. These young people seem to believe that their Christian vocation does indeed call them to that "spiritual formation...in theology, ethics and philosophy at least" which Apostolicam actuositatem considers "the foundation and condition of any fruitful apostolate" (Apostolicam actuositatem [1965] 1996, no. 29). Without this formation they become increasingly frustrated.

Both the pre-synod group and the subjects of the Saint Mary's Press/CARA study are also very concerned with the related issue of the relationship between faith and reason. The Pre-synodal text observes that "some perceive the Church to be 'anti-science' so its dialogue with the scientific community is also important, as science can illuminate the beauty of creation. In this context, the Church should also care for environmental issues, especially pollution" (Pre-Synodal Meeting of Young People 2018, no. 11). Several of the disaffiliated young people describe a similar difficulty: "as I started to enjoy math and science more, I just realized the discrepancy between science and religion. I guess that was another shaking point" (Saint Mary's Press of Minnesota and CARA 2017, p. 24). Another observed "there's a lot of contradictions that come with the bible and modern science. Also, I don't want to believe and worship a god who condemns them to hell for giving in to human nature" (Saint Mary's Press of Minnesota and CARA 2017, p. 62). In general, the CARA researchers observe that some who have disaffiliated "take issue with perceived Church teachings about the Bible, salvation, heaven, and life after death ... [T] hough many in this group [the Dissenters] were involved in Catholic education, parish religious education, and youth ministry, they expressed deep disillusionment and frustration that their questions were never answered or they didn't have the opportunity to voice their questions in the first place" (Saint Mary's Press of Minnesota and CARA 2017, pp. 21-22). In at least some cases, the perceived teachings, as articulated by the individuals, are inaccurate (a belief that the Catholic Church teaches a literal interpretation of the Bible requiring belief that "someone was swallowed by a whale and then came out") or theologically uncertain and under-developed: "I'm sure I'll be fine in the afterlife as long as I'm a good person" (Saint Mary's Press of Minnesota and CARA 2017, pp. 26, 62). 
The young people in these texts come from distinct subgroups within the same generation. One striking difference in their responses is the degree to which they indicate the influence of family and parents. The Pre-Synodal text mentions the importance of the family as a possible and privileged place for personality and vocational development (Pre-Synodal Meeting of Young People 2018, nos. 1, 9) and also makes a few references to experiencing the Church as a kind of family (Pre-Synodal Meeting of Young People 2018, no. 7). The subjects of the Saint Mary's Press/CARA study, particularly "the Drifters" make frequent mention of parents who changed denominations or stopped going to church altogether (Saint Mary's Press of Minnesota and CARA 2017, pp. 18-19, 58-59). While the Pre-Synodal group does not address particular parents at all, the disaffiliated young people indicate the specific influence of "sorta-Catholic" parents who, as the researchers observe "may sense the value of a faith community connection but may not be able to articulate their beliefs. [The researchers continue:] if parents feel inadequate to personally share their faith, or if they are also struggling to find genuine meaning in faith, then the family as a unit may be drifting" (Saint Mary's Press of Minnesota and CARA 2017, p. 19). The experiences of older generations also have a significant role to play. While families who play a stabilizing role in faith development seem almost taken for granted, families who are beginning to "drift" may point more strongly to the intergenerational influence of parents and family in faith development or disaffiliation.

Distinct as they may be, the young people whose voices are represented in these texts advocate for values that are in many ways in continuity with the teachings of the Second Vatican Council, albeit expressed in the key of twenty-first century cultures. As Edward Hahnenberg puts it, in the years since the Council, "what has changed ... is that what was once reserved for a few-namely, the quest for a deeper spiritual life-has now become the primary religious stance of most people" (Hahnenberg 2010, p. xii). These young people call for a Church that is both holy and authentic; they wish to be taken seriously as "full participants" who are capable of contributing on their own terms to the world that they inhabit, and they desire, or have in the past desired, theological conversations about doctrine and moral issues that respectfully address their own questions and experiences. These desires point to an understanding of baptismal identity that can contribute to the Church's evolving understanding and practice.

\section{The Potential of a Mystagogical Framework}

The challenges for an evolving understanding of baptismal identity abound in the twenty-first century Church. In addition to the issues addressed here, the relationship between marriage and baptism, ordination and baptism, and religious life and baptism continue to merit theological exploration. The question of the baptismal identity of the parents of these young people also looms large in the demographic analysis of twenty-first century Catholics. While the issues raised by the young people of the Pre-synodal Meeting and the Saint Mary's Press/CARA study contribute only a small section of the full picture, their frank insights offer a gift not only to the bishops at the synod but also to the broader Church.

This gift is a somewhat fragile one. Perhaps in recognition of that fragility, the responses of those who initiated the studies has been characterized by a tentative openness. In his Post-Synodal Apostolic Exhortation, Christus vivit, Pope Francis began by acknowledging that the process "raised issues that led me to ask new questions" (Francis 2019, no. 7). Similarly, the authors of the Saint Mary's Press/CARA study caution against "a rush to identify solutions or strategies that address the dynamics of disaffiliation" (Saint Mary's Press of Minnesota and CARA 2017, p. 32). They spend significant time, however, on "several initial questions they believe are important for pastoral ministry to address in light of the findings" (Saint Mary's Press of Minnesota and CARA 2017, p. 34). The topics that the researchers raise address key questions pertaining to operative understandings of Catholicity. They point to the need to "prioritize families on the margins" of Catholicism, those who are "sorta-Catholic" or "Catholic-ish" or who are baptized, but "don't fully accept and embrace the fullness of the Church's teachings and practices" (Saint Mary's Press of Minnesota and CARA 2017, 
p. 35). These fragile margins encompass not only the individuals who responded, but their parents and families as well as other lay Catholics who are "staying," "have left," are worried about adult children who no longer attend liturgy or are wrestling with their own consciences regarding their response to the public scandals that have wracked the Church. These people are not often consulted by the magisterium, but when their insights are collected by sociologists, they offer a valuable resource to theologians and pastoral ministers. ${ }^{8}$

It is important to heed the advice of the researchers who remind us not to seek conclusions or solutions too quickly. In light of this, I offer one possible approach for consideration. This approach is not a comprehensive "fix," nor does it provide a solution to the steady stream of disaffiliation. Instead it builds on the insights of the young people to engage the strengths and weaknesses of the baptismal vocation as it is currently lived and might be lived in the future. It is an approach in which the Church as a community might be invited to deepen and strengthen its understanding of baptismal identity through a process of communal reflection that is rooted in sacramental practice; in other words, it is a mystagogical approach.

In her 2012 Madeleva Lecture Becoming the Sign: Sacramental Living in a Post-Conciliar Church in which she addresses what she calls the "laity shortage" (Hughes 2013, p. 3), Kathleen Hughes describes mystagogy as "the opening up of the mysteries for believers through reflection on actual experience" (Hughes 2013, p. 77). In keeping with the insights offered by the young people, it is a process that is centrally concerned with fostering holiness in Christian life, is rooted in individual and communal experience, provides a foundation for more intensely theological study, and can be adapted as a kind of ongoing formation in the Christian life. As a means for developing and strengthening baptismal identity it is also a method that relies thoroughly on the participation of communities of the baptized themselves. It is not an approach that can be applied and carried out by "professionals" but rather a process that takes the insights of participants seriously.

The study and application of mystagogy, traditionally associated with the post-baptismal Easter preaching of bishops in the fourth and fifth centuries, has begun to be retrieved. This retrieval is not only to be found in the final and somewhat neglected "Period of Postbaptismal Catechesis or Mystagogy" in the Rite of Christian Initiation of Adults, (International Commission on English in the Liturgy [1988] 1990, nos. 244-251) but also in the broader pastoral and theological realm. ${ }^{9}$ Traditionally "the mysteries" which were opened up for new believers were the sacraments of initiation. The mystagogical preaching of bishops such as Cyril of Jerusalem, Theodore of Mopsuestia, John Chrysostom (Johnson 2007, pp. 120-34), and even Augustine of Hippo took place in the context of the Easter celebrations and involved a detailed spiritual and theological review of the liturgical rituals and their meanings. One example from the "Fifth Lecture on the Mysteries" by Cyril of Jerusalem is illustrative: "Next the deacon cries: 'Welcome one another,' and 'Let us kiss one another.' You must not suppose that this kiss is the kiss customarily exchanged in the streets by ordinary friends. This kiss is different, effecting as it does, a comingling of souls and mutually pledged forgiveness. The kiss, then, is a sign of true union of hearts, banishing every grudge. It was this that Christ had in view when He said: 'If, when you are bringing your gift to the altar, you suddenly remember that your brother has a grievance against you, leave your offering by the altar; first go and make your peace with your brother, and then come back to offer your gift'" (Cyril of Jerusalem 1970, no. 3). This excerpt from Cyril's preaching is characterized by a robust theological approach. First, Cyril is deeply grounded in the dialogue of the ritual text itself. In the course of his preaching, he takes the assembly through each liturgical phrase and gesture. Cyril moves from the ritual performance to a reference to everyday life; he is clear that although the meaning is different, the gestures of the liturgy are related to day-to-day

8 As Kathleen Hughes has recently pointed out: "People who care deeply about the church's sacramental life need to probe more deeply the implications of the Pew Forum and CARA studies and others like them" (Hughes 2013, p. 73).

9 In addition to the authors cited in this article, examples include, but are by no means limited to (Driscoll 2005; Elshof 2017; Mazza 1989; Ostdiek 2015; Rahner 1982; Vincie 2016). 
experience. The meaning of the gesture, however, has to do with two key tenets of Christian life: unity and forgiveness. Cyril then adds an additional layer of Biblical interpretation. This addition would have the effect of exposing the new Christians to a potentially new passage of the Bible, while also cementing the understanding that, as Louis-Marie Chauvet would put it one and a half millennia later, Scripture, Sacraments and Ethics are the marks of Christian identity. ${ }^{10}$

A mystagogical method is thus characterized by its foundation in liturgical and day-to-day experience. The mystagogical preaching of the fourth and fifth century church is peppered with exhortations to "call to mind" specific elements of the rite along with copious advice about how to engage the liturgy even more deeply "next time." It is a preaching that is rooted in past experience but is oriented towards future experience. While baptism and Eucharist are the sacraments traditionally associated with mystagogy, this is an approach that is easily expanded. Bruce Morrill describes the potential for mystagogy among the elderly after a celebration of the Anointing of the Sick: "During one or two more gatherings, set in the context of liturgical prayer, people could ... share their reflections on the experience of the sacrament as well as their feelings as they face the future, whether in the short or long term" (Morrill 2009, p. 181). In this case, the mystagogy begins and is rooted in the ritual text but can also be expanded to invite reflection on the experience of Christian life in older age. Such discussion, Morrill suggests, has the potential to further illuminate the Paschal Mystery both for the elderly and for their families and communities. This rediscovery that, "mystagogy is lifelong" (Hughes 2007, p. 14) further opens up the possibilities for its application as an approach to deepening baptismal identity.

The communal practice of drawing on personal experience in the context of the sacramental life also has some potential to meet young Catholics where they are in terms of their emphasis on personal experience and their preference for a "'literature of life' [rather] than an abstract theological discourse." It also has the potential to address the concern that the Pre-synodal group raised about sacramental and intellectual formation. "Because of the lack of clear and attractive presentation as to what the Sacraments truly offer, some of us go through the process of receiving but undervaluing them (Pre-Synodal Meeting of Young People 2018, no. 14). Here, the theological explanation can be deployed specifically so that participants might engage the liturgy more deeply and live more fully according to authentic Christian tradition. For example, participants of all sorts might gather after the Easter baptisms or after a baptism at a Sunday liturgy to reflect on their experience of the ritual celebration. In light of this experience, the community could begin to develop for itself a deeper sense of what baptismal identity means both for the newly baptized and for other baptized members of the community.

Mystagogy today necessarily seeks to elicit frank conversation about individual experiences within the context of a communal sacramental experience. As Hughes puts it, "The key to mystagogical reflection is that it is subjective rather than objective; it is about my experience and your experience of an encounter with God through the sacramental celebration ... It relates experience and symbol and takes both utterly seriously" (Hughes 2007, p. 15). An authentic mystagogical experience must also be open to the sometimes negative experiences that accompany sacramental celebration. One particularly plaintive response from the Saint Mary's Press/CARA study to the question "What are the reasons that explain why you are no longer Catholic?" is as follows: "Because the church forgot about me during my 1st communion, \& then our priest was arrest[ed] for sexual assault on a minor" (Saint Mary's Press of Minnesota and CARA 2017, p. 51). The experience of being forgotten during First Communion would necessarily color an individual's experiential understanding of Eucharist.

10 While beyond the scope of this paper, Chauvet's understanding of the marks of the church can also provide a helpful conversation partner in terms of baptismal identity. Chauvet argues that the Church "has existence and meaning only because of its relationship to the reign, which in the world is wider than it .... it is not the reign; it is only its sacrament. But that fact of being its sacrament ... demands that it be the sign of the reign, and therefore that it show the marks of the reign" (Chauvet 2001, p. 29). 
In this context, the mystagogical reflection would have to be expanded to include not only the usual topics of Eucharistic theology, but also the pain of exclusion, and perhaps also betrayal in light of the community's experience of a predatory priest. "For mystagogy to be successful, we need to be able to identify and talk about our experience. That demands that we know what our experience is, that we are in touch with our inner world, and attentive to what we are doing when we gather for prayer" (Hughes 2007, p. 15). It might be added that successful mystatogy in our time may also demand work to restore the trust that has been lost in many communities. Mystagogy is a process of recognizing grace, and it also bears the potential for frank discussions of sin and reconciliation in the context of community. It should not become a forum for liturgical planning, however a deeper understanding of one another's experience, expressed in a prayerful context, can become a catalyst for liturgical development.

As Cyril of Jerusalem's preaching demonstrated, and Morrill's example illustrated, mystagogical practice can lead from the experience of the sacraments to an incorporation of the experience of Christian life. Paul Crowley argues, that in addition to communal liturgical reflection on the sacraments, it is also possible to use "the word 'mystagogy' in its root sense of guiding an initiate into the world of faith, into its depths as they are realized interpersonally in God" (Crowley 2015, p. 12). Crowley regards this as a useful approach for all Christians in the West, but particularly for those, both affiliated and disaffiliated, who struggle with belief. As the two texts that we have engaged indicate, both closely affiliated and disaffiliated young people share the same world. "Some have lost the ability to believe, not because they do not know what the church has proposed for belief, but because the doctrinal 'content' of faith has become intellectually incredible, as belonging to another world of meaning and reference and certainly not to the world of empirical demonstration" (Crowley 2015, p. 8). Even those who value their faith and wish to believe may run into difficulties when their meager, often exclusively catechetical rather than theological, education comes into contact with tens of undergraduate credits in STEM education. As one participant in the Saint Mary's Press/CARA study reported, s/he "stopped being religious because I began to learn more about the world. It became impossible to believe in the things taught by religion. No matter how hard I tried to believe in it, the knowledge I gained made it impossible" (Saint Mary's Press of Minnesota and CARA 2017, p. 56). A mystagogical framework is helpful in that it builds on experience and community to integrate Christian life in the context of a shared world. Grounded in the practice of ritual experience, it guards against the temptation to forget that "the transcendent has entered into the natural world and established it as the place of divine revelation" (Crowley 2015, p. 21). ${ }^{11}$ It insists that humanity is not alone in the world, struggling against an unreasonable, uncaring, and disembodied God. Here the presence of God is to be discerned in one's own shared experience of sacramental liturgy and a Christian life "on the path to holiness" in relationship to the world. Guiding this process is the task of leaders, or perhaps "mentors" in today's language, who accompany others among the faithful as they "move from a vague awareness of the mystery dimension of their lives to a greater conception and affective clarity, and ... find a proper way to continue to allow experience and expression to inform one another" (Hughes 2007, p. 15).

In order for sound mystagogy, both of liturgy and of life, to take place however, those guiding the mystagogical process must have sufficient theological education. As Cyril of Jerusalem's example indicates, the person serving as guide to the mysteries must be theologically adept, profoundly familiar with the patterns of liturgy and life, and able to negotiate comfortably between liturgical, moral, and biblical theologies. These guides must be capable of sharing and eliciting theological insights that are

11 "There is a sense in which the saeculum is established so that this revelation can take place: the locus of revelation is in fact the saeculum. The Word (Logos) creates the conditions of its very possibility of appearance within the created order." As Crowley cautions, "when Christian faith forgets this and separates itself in opposition to the very world that it otherwise hallows, it can degenerate into ideology. The secular world becomes the enemy, rather than the theater of lived religion that Christianity has otherwise hallowed. Believing becomes reduced to rational assent to culturally unintelligible propositions" (Crowley 2015, p. 21). 
"not watered down, or ... utiliz[ing] pre-fabricated formulations" (Pre-Synodal Meeting of Young People 2018, no. 11). They must be able to avoid falling into ideology, inadvertently reducing believing to what Crowley refers to as an attempt at "rational assent to culturally unintelligible propositions" (Crowley 2015, p. 21). To achieve this task, pastors, Catholic high school employees, CCD teachers, and youth ministers must be trained not only in catechesis and pedagogy suitable to various stages of human development, but they must also be theologically adept, and free from narrow catechetical curricula, in order to facilitate the serious theological discussions about science and religion, biblical hermeneutics, and thorny issues of eschatology for which young people are calling. They must not only know what the tradition says, but, as theologically informed ministers, also be able to apply it to the real theological questions that young people are asking. This need becomes increasingly urgent as Catholic colleges and universities in the US continue to slash theology and philosophy requirements (Hollerich 2018).

A mystagogical approach does not propose a solution to the many problems that the church faces, but it offers a structure in which communities can seek to deepen their understanding and practice of their baptismal identities through reflection on liturgical experience, sound theological engagement, and communal practice of the Christian life. It offers a space in which the kind of mentor that young people seek can continue to be formed as "a faithful Christian who engages with the Church and the world; someone who constantly seeks holiness; is a confidant without judgement; actively listens to the needs of young people and responds in kind; is deeply loving and self-aware; acknowledges their limits and knows the joys and sorrows of the spiritual journey" (Pre-Synodal Meeting of Young People 2018, no. 1). In this space, young and old can strengthen the bonds between the center and the margins in their conscious and self-reflective pursuit of holiness, their participation and encouragement of participation in the modern world, their respect for the human dignity of all, and their pursuit of the theological education that must necessarily ground Christian life in the world. In so doing, they will strengthen their own baptismal identity and become more equipped to mentor the generations that they hope will follow them.

\section{Conclusions}

As the number of baptisms decline and as young individuals disaffiliate from the church, in part because the practicing baptized have disappointed them, the need for a deeper understanding of what baptismal identity can and should be becomes increasingly urgent. These two groups of young people have articulated their need for a Church that is on the path to holiness, respectfully engaged with the modern world, and able to articulate the faith with clarity and authenticity in light of contemporary experience. Their consensus around these issues offers a starting point for others in the church to consider the baptismal vocation that is common to all the faithful. A mystagogical approach to the development of baptismal identity, while not an immediate solution to Christian challenges in any of these areas, can offer a framework that is both traditional and forward pointing, contemplative and active, sacramental and oriented ad extra. Grounded in the process of baptismal formation, it brings the lived experience of sacramental celebration into conversation with baptismal identity in the world, inviting all the faithful, young and old, lay and ordained, married and single, to deepen their participation in the liturgy and Christian life and in so doing to hold the inter-generational community of the baptized together in the larger context of the communion of saints. The young people of the Pre-synodal preparations and the Saint Mary's Press/CARA study are inviting the rest of the Church to ponder with them what it means to live a Christian life grounded in the baptismal vocation. In fact, they are inviting, if not begging, the church to live this baptismal identity in order fruitfully to "walk alongside them" as mentors and companions. Members of the baptized faithful ignore this urgent invitation at our peril.

Funding: This research received no external funding.

Conflicts of Interest: The author declares no conflict of interest. 


\section{References}

Apostolicam actuositatem. 1996. Vatican Council II: The Basic Sixteen Documents. Edited by Austin Flannery. Northport: Costello Publishing. First published 1965.

CARA. 2019. Frequently Requested Church Statistics. Available online: https://cara.georgetown.edu/frequentlyrequested-church-statistics/ (accessed on 29 July 2019).

Chauvet, Louis-Marie. 2001. The Sacraments: The Word of God at the Mercy of the Body. Collegeville: Liturgical Press.

Congar, Yves. 2011. True and False Reform in the Church. Translated by Paul Philibert. Collegeville: Liturgical Press. First published 1967.

Cox, Kathryn Lilla. 2015. Water Shaping Stone: Faith, Relationships, and Conscience Formation. Collegeville: Liturgical Press.

Crowley, Paul. 2015. Mystagogy and Mission: The Challenge of Nonbelief and the Task of Theology. Theological Studies 76: 7-28. [CrossRef]

Cyril of Jerusalem. 1970. Fifth Lecture on the Mysteries. In The Works of Saint Cyril of Jerusalem, vol 2. Edited by Bernard M. Peebles. Washington, DC: Catholic University of America Press.

Driscoll, Michael. 2005. Musical Mystagogy: Catechizing Through the Sacred Arts. In Music in Christian Worship: At the Service of the Liturgy. Edited by Charlotte Kroeker. Collegeville: Liturgical Press, pp. 27-44.

Elshof, A. J. M. 2017. Mystagogy, religious education and lived catholic faith. Journal of Religious Education 64: 143-55. [CrossRef]

Faggioli, Massimo. 2012. Vatican II and the Church of the Margins. Theological Studies 72: 808-18.

Francis, Pope. 2019. Christus vivit. Available online: http://w2.vatican.va/content/francesco/en/apost_exhortations/ documents/papa-francesco_esortazione-ap_20190325_christus-vivit.html (accessed on 29 July 2019).

Gaillardetz, Richard. 2014. The "Francis Moment": A New Kairos for Catholic Ecclesiology. Catholic Theological Society of America Proceedings 69: 63-80.

Gaudium et spes. 1996. Vatican Council II: The Basic Sixteen Documents. Edited by Austin Flannery. Northport: Costello Publishing. First published 1965.

General Secretariat of the Synod of Bishops. 2018a. The World of New Generations According to the Online Questionnaire. Rome: Libreria Editrice Vaticana, Available online: http://www.synod2018.va/content/ dam/synod2018/documenti/Libri/libro\%20mondo\%20delle\%20nuove\%20generazioni.pdf (accessed on 29 July 2019).

General Secretariat of the Synod of Bishops. 2018b. Young People, The Faith and Vocational Discernment. Available online: http://www.synod.va/content/synod2018/en/news/book--the-world-of-new-generationsaccording-to-the-online-quest.html (accessed on 29 July 2019).

Grimes, Katie. 2017a. Breaking the Body of Christ: The Sacraments of Initiation in a Habitat of White Supremacy. Political Theology 18: 22-43. [CrossRef]

Grimes, Katie. 2017b. Christ Divided: Antiblackness as Corporate Vice. Minneapolis: Fortress Press.

Hahnenberg, Edward P. 2010. Awakening Vocation: A Theology of Christian Call. Collegeville: Liturgical Press.

Hollerich, Michael. 2018. Do Catholic Theology Departments Have a Future?: A Response to Massimo Faggioli. Commonweal. Available online: https://www.commonwealmagazine.org/do-catholic-theology-departmentshave-future (accessed on 29 July 2019).

Hughes, Kathleen. 2007. Saying Amen: A Mystagogy of the Sacraments. Chicago: Liturgical Training Publications.

Hughes, Kathleen. 2013. Becoming the Sign: Sacramental Living in a Post-Conciliar Church. Mahwah: Paulist Press.

International Commission on English in the Liturgy. 1990. Rite of Christian Initiation of Adults. In The Rites of the Catholic Church. vol. 1. Collegeville: Liturgical Press. First published 1988.

John Paul, Pope, II. 1988. Christifideles laici. Available online: http://w2.vatican.va/content/john-paul-ii/en/apost_ exhortations/documents/hf_jp-ii_exh_30121988_christifideles-laici.html (accessed on 29 July 2019).

Johnson, Maxwell. 2007. The Rites of Christian Initiation: Their Evolution and Interpretation. Revised and Expanded Edition. Collegeville: Liturgical Press.

Lumen gentium. 1996. Vatican Council II: The Basic Sixteen Documents. Edited by Austin Flannery. Northport: Costello Publishing. First published 1964.

Mazza, Enrico. 1989. Mystagogy: A Theology of Liturgy in the Patristic Age. Collegeville: Liturgical Press.

McGrady, Katie Prejean. 2018. The synod on young people needs to listen to all voices-Catholic or not. America Magazine. Available online: https://www.americamagazine.org/faith/2018/03/29/synod-young-people-needslisten-all-voices-catholic-or-not (accessed on 29 July 2019). 
Morrill, Bruce. 2009. Divine Worship and Human Healing: Liturgical Theology at the Margins of Life and Death. Collegeville: Liturgical Press.

Ostdiek, Gilbert. 2015. Mystagogy of the Eucharist: A Resource for Faith Formation. Collegeville: Liturgical Press.

Pre-Synodal Meeting of Young People. 2018. Final Document from the Pre-Synodal Meeting. Available online: http: //www.synod.va/content/synod2018/en/news/final-document-from-the-pre-synodal-meeting.html (accessed on 29 July 2019).

Rahner, Karl. 1982. Reflections on Methodology in Theology. In Confrontations. Theological Investigations. Translated by David Bourke. New York: Crossroad, vol. 11, pp. 68-114.

Saint Mary's Press of Minnesota and CARA. 2017. Going, Going, Gone: The Dynamics of Disaffiliation in Young Catholics. Winona: Saint Mary's Press.

United States Conference of Catholic Bishops. 2019. Synod 2018: Information and FAQs. Available online: http://www.usccb.org/about/bishops-and-dioceses/synod-of-bishops/synod-2018/synod2018-information-and-faqs.cfm (accessed on 29 July 2019).

Vincie, Catherine. 2016. Mystagogical Preaching. In A Handbook for Catholic Preaching. Edited by Edward Foley. Collegeville: Liturgical Press, pp. 134-45.

Zenner, Christiana. 2018. Just Water: Theology, Ethics, and Fresh Water Crises, rev. ed. Maryknoll: Orbis.

(C) 2019 by the author. Licensee MDPI, Basel, Switzerland. This article is an open access article distributed under the terms and conditions of the Creative Commons Attribution (CC BY) license (http://creativecommons.org/licenses/by/4.0/). 